\title{
KAJIAN PENINGKATAN MUTU BRIKET ARANG TEMPURUNG KELAPA DENGAN ALAT PENGERING TIPE RAK BERBAHAN BAKAR BIOMASSA
}

\section{THE STUDY OF QUALITY IMPROVEMENT OF CHARCOAL BRIQUETTE MADE OF COCONUT SHELL WITH BIOMASS-FUEL TRAY DRYER}

\author{
Dimas Rahadian Aji Muhammad ${ }^{1)}$, Nur Her Riyadi Parnanto ${ }^{1)}$, Fanny Widadie ${ }^{1)}$ \\ ${ }^{1)}$ Fakultas Pertanian, Universitas Sebelas Maret, Surakarta \\ Email: rahadiandimas@yahoo.com
}

\begin{abstract}
Charcoal briquette made of coconut shell is one of alternative energy sources which has high demand in export market. As the export commodity, the quality of charcoal briquette should be stable as well as fulfill the requirements of quality due to the market. Implementation of biomass-fuel tray dryer is needed for producing the product on constant moisture content and fulfilling quality requirement of the market. This research aimed to understand the effect of implementation of the dryer to charcoal briquette compared to natural drying. The analysis was including moisture content, ash content, and fixed carbon. The analysis showed that aplication of the dryer can improve the quality of charcoal briquette compared to natural drying.
\end{abstract}

Keywords: charcoal briquette, coconut shell, dryer, quality

\begin{abstract}
ABSTRAK
Briket arang tempurung kelapa merupakan salah satu sumber energi alternatif yang diminati oleh pasar ekspor. Sebagai komoditas ekspor, mutu briket arang harus stabil dan dapat memenuhi persyaratan mutu pasar yang dituju. Implementasi alat pengering tipe rak berbahan bakar biomassa diperlukan untuk menghasilkan briket arang dengan kadar air yang konstan dan memenuhi persyaratan mutu pasar. Tujuan dari penelitian ini adalah untuk mengetahui pengaruh penggunaan alat pengering tipe rak berbahan biomassa terhadap briket arang dibandingkan dengan pengeringan matahari. Analisa yang dilakukan meliputi kadar air, kadar abu, dan kadar karbon terikat. Hasil analisa menunjukkan bahwa aplikasi alat pengering dapat meningkatkan mutu briket arang apabila dibandingkan dengan pengeringan matahari.
\end{abstract}

Kata kunci: alat pengering, briket arang, mutu, tempurung kelapa

\section{PENDAHULUAN}

Kebutuhan energi mengalami peningkatan seiring dengan laju pertumbuhan populasi dan ekonomi dunia. Di Indonesia, dalam Blue Print Pengelolaan Energi Nasional 2006-2025 yang dirilis oleh Kementerian Energi dan Sumber Daya Mineral (ESDM), kebijakan energi Indonesia memiliki sasaran antara lain pada tahun 2025 akan tercapai penurunan peranan minyak bumi menjadi $26.2 \%$, gas bumi meningkat menjadi $30.6 \%$, batubara meningkat menjadi $32.7 \%$ (termasuk briket batubara), panas bumi meningkat menjadi $3.8 \%$, dan energi terbarukan meningkat menjadi 15\% (Anonim, 2006). Briket arang yang terbuat dari tempurung kelapa merupakan salah bentuk energi terbarukan yang layak dikembangkan di Indonesia. Data dari Kementerian Pertanian Republik Indonesia menyatakan bahwa luas perkebunan kelapa di Indonesia pada tahun 2009 mencapai 3,8 juta hektar dengan jumlah produksi 3,2 juta ton (Anonim, 2012). Diperkirakan dalam satu ton kelapa, tempurung kelapa yang dihasilkan mencapai $150 \mathrm{~kg}$.

Menurut Adan (1998), keuntungan pemakaian briket arang antara lain, biayanya lebih murah dibandingkan dengan minyak atau arang kayu, briket arang memiliki masa bakar yang jauh lebih lama, penggunaan briket relatif lebih aman, briket mudah disimpan dan dipindah-pindahkan, tidak perlu berkali-kali mengipasi atau menambah dengan bahan bakar yang baru. Dengan berbagai keunggulan tersebut, peran briket arang sebagai bahan bakar alternatif telah diakui di berbagai negara. Sejak tahun 2003 tercatat permintaan briket arang di Sulawesi Tengah dari salah satu perusahaan eksportir adalah sebesar 1.800 ton per tahun. Secara keseluruhan ekspor arang briket tahun 2003 mencapai 26.360,6 ton dengan nilai US\$ 4.699.147 (Anonim, 2004).

PT. Tropica Nucifera Industry adalah sebuah industri kecil di Yogyakarta yang memproduksi briket arang tempurung kelapa. 
Dalam satu bulan, kapasitas produksi PT Tropica Nucifera Industry adalah 28 ton. Jumlah permintaan briket untuk local ratarata 5 ton per bulan, sedangkan untuk permintaan ekspor setiap 2 bulan ke Singapura 28 ton. Selain itu, briket arang yang diproduksi PT. Tropica Nucifera Industry juga telah dipasarkan di timur tengah sebagai bahan bakar sisha. Namun, pemenuhan permintaan ekspor ini terkendala dengan cuaca, sebab pengeringan yang dilakukan PT Tropica Nucifera Industry masih menggunakan panas matahari. Hal ini menyebabkan kadar air briket tidak konstan. Padahal kadar air merupakan salah satu parameter paling penting dalam penentuan kualitas briket arang. Oleh karena itu, diperlukan introduksi alat pengering untuk meningkatkan kualitas briket arang. Tujuan dari penelitian ini adalah mengetahui pengaruh penggunaan alat pengering tipe rak berbahan bakar tempurung kelapa terhadap peningkatan kualitas briket arang tempurung kelapa dibandingkan dengan pengeringan matahari.

\section{METODE PENELITIAN}

\section{Bahan dan Alat}

Bahan yang digunakan adalah briket arang tempurung kelapa yang diperoleh dari PT Tropica Nucifera Industry yang berlokasi di Yogyakarta.

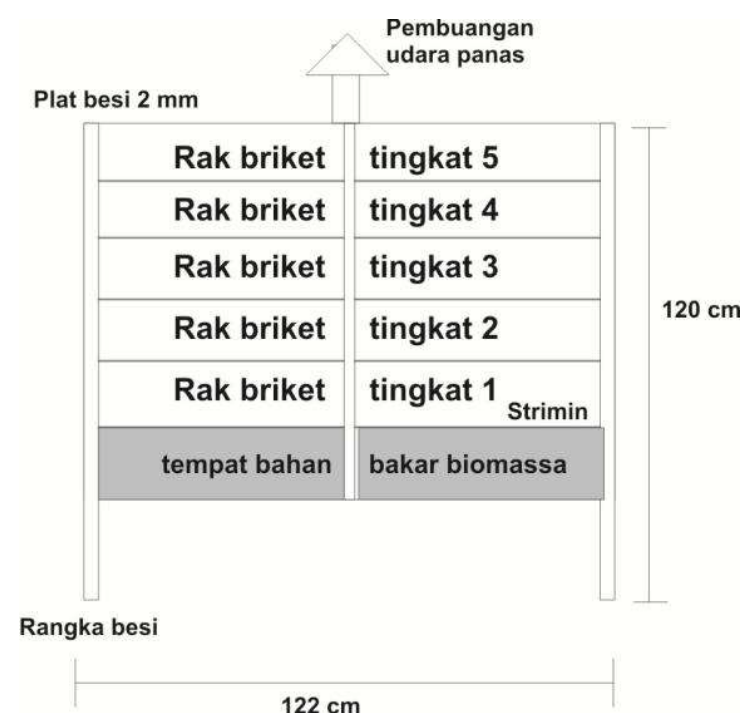

Gambar 1. Tray Dryer Berbahan Bakar Biomassa
Alat yang digunakan untuk proses pengeringan briket arang adalah tray dryer dengan bahan bakar tempurung kelapa. Alat tersebut terbuat dari lempengan besi ketebalan $2 \mathrm{~mm}$ dengan dimensi $122 \mathrm{~cm}$ x 50 $\mathrm{cm} \times 120 \mathrm{~cm}$. Kapasitas pengeringan tray dryer adalah $60 \mathrm{~kg}$ briket briket arang per batch. Waktu proses pengeringan untuk setiap batch adalah 5 menit. Gambar oven berbahan bakar biomassa dapat dilihat pada Gambar 1.

\section{Metode Analisis}

Analisis yang dilakukan meliputi kadar air (metode gravimetri), kadar abu (metode gravimetri), dan fixed carbon (metode gravimetri).

\section{HASIL DAN PEMBAHASAN}

Briket arang tempurung kelapa yang dikeringkan dengan sinar matahari dibandingkan dengan pengeringan menggunakan tray dryer berbahan bakar biomassa dapat dilihat pada Tabel 1.

\section{Kadar Air}

Tabel 1 menunjukkan bahwa pengeringan menggunakan alat pengering berbahan bakar biomassa menghasilkan kadar air yang lebih rendah dibandingkan kadar air briket arang tempurung kelapa yang dikeringkan dengan sinar matahari. Hal ini disebabkan panas konveksi yang dihasilkan biomassa yang dibakar mempunyai kapasitas pengeringan yang dapat membawa uap air. Kadar air briket tempurung yang dikeringkan dengan tray dryer adalah 6,39\%, sedangkan kadar air briket tempurung yang dikeringkan dengan sinar matahari 15,89\%. Kadar air briket arang yang dikeringkan dengan tray dryer telah memenuhi persyaratan mutu briket arang menurut SNI 01-6235-2000 yang menyebutkan bahwa kadar air maksimal briket arang adalah $8 \%$, serta persyaratan mutu yang ditetapkan oleh Jepang, yaitu 6-8\%. Dengan demikian, alat pengering ini terbukti dapat meningkatkan kualitas briket arang tempurung kelapa.

Kadar air merupakan parameter penting untuk menentukan kualitas briket arang. Kadar air berpengaruh secara langsung terhadap parameter mutu briket 
Tabel 1. Perbandingan Kualitas Briket Arang Tempurung Kelapa

\begin{tabular}{lcccc}
\hline \multicolumn{1}{c}{ Parameter } & $\begin{array}{c}\text { Sinar } \\
\text { Matahari }\end{array}$ & $\begin{array}{c}\text { Tray dryer berbahan } \\
\text { bakar biomassa }\end{array}$ & Jepang ${ }^{*}$ & $\begin{array}{c}\text { SNI } \\
\text { 01-6235-2000*) }\end{array}$ \\
\hline Kadar air & $15,89 \%$ & $6,39 \%$ & $6-8 \%$ & $8 \%$ \\
Kadar abu & $2,57 \%$ & $2,65 \%$ & $3-6 \%$ & $8 \%$ \\
Karbon Terikat & $77,32 \%$ & $85,83 \%$ & $60-80$ & $77 \%$ \\
\hline${ }^{*}$ ) & & &
\end{tabular}

${ }^{*}$ Sumber: Badan Penelitian dan Pengembangan Kehutanan (1994)

arang lainnya, antara lain nilai kalor dan keteguhan. Haygreen dan Bowyer (1989) menjelaskan bahwa semakin tinggi kadar air, semakin rendah nilai kalornya. Hal ini disebabkan karena panas yang tersimpan dalam briket terlebih dahulu digunakan untuk mengeluarkan air yang ada sebelum kemudian menghasilkan panas yang dapat dipergunakan sebagai panas pembakaran. Dengan demikian dapat diartikan bahwa semakin tinggi kadar air, briket arang akan semakin sulit dibakar, demikian juga sebaliknya. Nilai kalor juga merupakan salah satu sifat utama yang menentukan kualitas briket. Semakin tinggi nilai kalor yang dihasilkan, briket arang tersebut semakin baik kualitasnya.

Danang (1998) menyebutkan bahwa kadar air juga berpengaruh terhadap keteguhan briket. Semakin tinggi kadar air, maka briket arang akan semakin rapuh. Selanjutnya sifat keteguhan ini mempengaruhi mudah tidaknya briket arang pecah bila dikenai tekanan.

\section{Kadar Abu}

Dalam Tabel 1, ditunjukkan bahwa kadar abu briket arang yang dikeringkan dengan tray dryer lebih tinggi dibandingkan dengan kadar abu briket arang yang dikeringkan dengan matahari. Namun kadar abu yang dihasilkan masih di bawah batas yang ditetapkan oleh Jepang dan SNI. Abu merupakan bagian yang tersisa dari hasil pembakaran briket arang. Menurut Djajeng dan Wisnu (2009), kadar abu yang tinggi dapat menurunkan nilai kalor briket arang sehingga kualitas briket arang tersebut menurun. Dengan demikian, semakin rendah kadar abu, maka kualitas briket arang semakin baik.

Hartoyo dan Nurhayati (1976) menyebutkan bahwa kadar abu juga berpengaruh terhadap kadar karbon terikat.
Kadar abu tinggi menyebabkan kadar karbon terikat menjadi rendah atau sebaliknya. Karbon terikat juga merupakan salah satu parameter mutu briket arang.

\section{Karbon Terikat}

Tabel 1 menunjukkan bahwa kadar karbon terikat pada briket arang yang dikeringkan dengan tray dryer lebih tinggi dibandingkan dengan briket arang yang dikeringkan dengan sinar matahari, sekaligus lebih tinggi dibandingkan standar yang ditetapkan Jepang dan SNI. Kadar karbon terikat adalah fraksi karbon (C) yang terikat di dalam arang selain fraksi air, zat menguap, dan abu. Kadar karbon terikat berpengaruh terhadap nilai kalor briket arang. Semakin tinggi kadar karbon terikat semakin tinggi nilai kalornya (Djajeng dan Wisnu, 2009). Dengan demikian, dapat disimpulkan bahwa semakin tinggi kadar karbon terikat maka kualitas briket arang tersebut semakin baik.

\section{Konsep Alat Pengering Zero Waste}

Alat pengering yang digunakan berbahan bakar tempurung kelapa. Arang dari tempurung kelapa yang telah terbakar, selanjutnya dapat diolah lebih lanjut menjadi briket arang dengan proses penggilingan, pengayakan, pencampuran dengan bahan perekat, pencetakan, dan pengeringan. Demikian seterusnya, sehingga alat pengering yang diaplikasikan pada PT Tropica Nucifera Industry tidak menghasilkan limbah dan hemat energi.

\section{KESIMPULAN DAN SARAN}

Penerapan alat pengering dapat meningkatkan mutu briket arang tempurung kelapa dibandingkan dengan pengeringan matahari, yaitu menurunkan kadar air dan meningkatkan kadar karbon terikat. Kadar abu briket arang yang dikeringkan dengan 
alat pengering meningkat, namun masih di bawah standar yang dipersyaratkan Jepang dan SNI. Alat pengering yang diimplementasikan mengacu pada konsep zero waste dan hemat energi. Namun, masih diperlukan perhitungan biaya operasi pengeringan.

\section{UCAPAN TERIMA KASIH}

Kegiatan ini dilaksanakan melalui Program IPTEKS bagi Produk Ekspor (IbPE) yang dibiayai oleh Dana BOPTN Tahun 2012 dengan nomor kontrak 2018A/UN27.7/PP/2012.

\section{DAFTAR PUSTAKA}

Anonim, 2004. Profil Proyek Industri Briket Arang Tempurung Kelapa. Badan Koordinasi Penanaman Modal Daerah Sulawesi Tengah. Di unduh pada tanggal 20 November 2012 pada website http://radiks.files.wordpress.com/2010/09 /briket.pdf

Anonim, 2006. Blue Print Pengelolaan Energi Nasional 2006-2025. Jakarta: Kementerian Energi dan Sumber Daya Mineral (ESDM). Diunduh pada tanggal 20 November 2012 pada website http://psdg.bgl.esdm.go.id/kepmen_pp_u u/blueprint_PEN.pdf

Anonim, 2012. Luas Areal dan Produksi Perkebunan Seluruh Indonesia Menurut Pengusahaan. Di unduh pada tanggal 20 November 2012 pada website http:/ditjenbun.deptan.go.id/cigraph/inde x.php/viewstat/komoditiutama/5-Kelapa

Adan, Ismun Uti. 1998. Membuat Briket Bioarang. Penerbit Kanisius : Yogyakarta.

Danang Sudiatmoko, 1998. Pemanfaatan Limbah Tempurung dan Campurannya dengan Tandan dan Sabut Kelapa Sawit Menjadi Arang Briket. Skripsi Jurusan Teknologi Pengolahan Hasil Pertanian Universitas Gadjah Mada. Yogyakarta

Djajeng Sumangat dan Wisnu Broto. 2009. Kajian Teknis dan Ekonomis Pengolahan Briket Bungkil Biji Jarak Pagar Sebagai Bahan Bakar Tungku. Buletin Teknologi Pascapanen Pertanian Vol. 52009
Hartoyo dan Nurhayati, 1978. Rendemen dan Sifat Arang dari Beberapa Jenis Kayu Indonesia. Buku Laporan Lembaga Penelitian Hasil Hutan. Departemen Kehutanan. Bogor

Haygreen, J.G. dan J.L. Bowyer, 1989. Hasil Hutan dan Ilmu Kayu, Suatu Pengantar. Terjemahan oleh Sutjipto A. Hadikusumo (1989). Gadjah Mada University Press. Yogyakarta. 